\title{
Utilizing Formative Assessment to Encourage Study Strategy Modifications by Osteopathic Medical Students: An Observational Study
}

\author{
Osteopatik Tıp Öğrencilerinin Çalışma Stratejisi Değişikliklerini Teşvik Etmek için Biçimlendirici \\ Değerlendirmeden Yararlanmak: Gözlemsel Bir Çalışma
}

\author{
Vivek JOSHI ${ }^{1}$ \\ (D) 0000-0002-0369-9502 \\ Michael YOUNGER ${ }^{1}$ \\ (D) 0000-0002-9441-9915 \\ Bhargavi JOSHI ${ }^{2}$ \\ (D) 0000-0002-1389-9719 \\ Safeer KHAN ${ }^{3}$ \\ (D) 0000-0002-0017-7928
}

\begin{abstract}
Aim: The standardized mode of delivering curriculum across the globe is didactic lectures. Formative and summative assessment methods are routine practices used to assess the students understanding and mastery in content and concepts which is delivered. The formative assessment methods are extremely popular in medical educational training but the data supporting such claims is largely lacking. The aim of this observational study was to determine if frequently provided formative assessment methods like practice quizzes, take home assignments can have any positive impact on student learning strategies and assessment outcomes in examination.

Material and Methods: A total of 145 students were included in this study. This study explored the relationship between student performance in various low stakes formative quizzes and high stakes summative examination. Based on the student performances across various formative assessment methods, the students were encouraged to modify or retain the study strategies and the effect of such recommendations were observed over the course of the semester.

Results: The data analysis showed positive relationship between the student performance on formative assessments and summative assessment before and after the intervention to study methods and strategies. Students in top, second, third and bottom quartile gained a cumulative average of $72.4 \%, 61.0 \%, 56.6 \%$ and $48.3 \%$ in the formative assessment and an average of $89.3 \%, 79.8 \%, 75.0 \%$, and $65.7 \%$ on their summative examination which were used as tools for early intervention.

Conclusion: Following the early intervention and modifications in study strategies, there was a steady increase in student performance on high stakes examination.

Keywords: Formative assessment; audio visual resources; early intervention; osteopathic medical students; feedback loop; knowledge gap.
\end{abstract}

\section{ÖZ}

Amaç: Tüm dünyada müfredatın standart olarak veriliş şekli didaktik derslerdir. Biçimlendirici ve belirleyici değerlendirme yöntemleri, öğrencilerin verilen içerik ve kavramları anlama ve kullanma becerilerini değerlendirmek için kullanılan rutin uygulamalardır. Biçimlendirici değerlendirme yöntemleri tıp eğitim öğretiminde son derece popülerdir, ancak bu iddiaları destekleyen veriler açısından büyük ölçüde eksiklik söz konusudur. Bu gözlemsel çalışmanın amacı, uygulama sınavları, ev ödevleri gibi sıklıkla kullanılan biçimlendirici değerlendirme yöntemlerinin, öğrencilerin öğrenme stratejileri ve sınavdaki değerlendirme sonuçları üzerinde olumlu bir etkisi olup olmadığını belirlemektir. Gereç ve Yöntemler: Bu çalışmaya toplam 145 öğrenci dahil edildi. Bu çalışmada, çeşitli düşük riskli biçimlendirici sınavlar ve yüksek riskli belirleyici sınavlardaki öğrenci performansı arasındaki ilişki araştırıldı. Çeşitli biçimlendirici değerlendirme yöntemlerinde öğrenci performanslarına dayalı olarak, öğrenciler çalışma stratejilerini değiştirmeye veya korumaya teşvik edildi ve bu önerilerin etkisi dönem boyunca gözlemlendi.

Bulgular: Veri analizi sonucunda, çalışma yöntem ve stratejilerine müdahaleden önce ve sonra ögrencilerin biçimlendirici değerlendirme ve belirleyici değerlendirme performansı arasında pozitif bir ilişki olduğu gösterilmiştir. Üst, ikinci, üçüncü ve alt çeyrekte yer alan öğrenciler, erken müdahale için bir araç olarak kullanılan biçimlendirici değerlendirmede kümülatif ortalama $\% 72,4 ; \% 61,0 ; \% 56,6$ ve $\% 48,3$ alırken belirleyici sınavlarında ise ortalama $\% 89,3$; $\% 79,8 ; \% 75,0$ ve $\% 65,7$ puan almışlardır.

Sonuç: Çalışma stratejilerindeki erken müdahale ve değişiklikler sonrasında, yüksek riskli sınavlarda öğrenci performansında sürekli bir artış olmuştur.

Anahtar kelimeler: Biçimlendirici değerlendirme; görsel-işitsel kaynaklar; erken müdahale; osteopatik tıp öğrencileri; geribildirim döngüsü; bilgi boşluğu.
Accepted / Kabul Tarihi : 03.04.2021 Available Online /

Çevrimiçi Yayın Tarihi : 18.04.2021 


\section{INTRODUCTION}

Medical education has become an assessment-driven system all over the globe. The pressure on the assessment methods and its success has been the focus as sound assessment of medical education serves the public interest. It is not a sudden change to assessment-based intrinsic motivation to study student learning but it has been a gradual transition, and it has come to the forefront as educational institutions strive to improve the effectiveness of student learning specially when the learning group is large with limited faculty (1-3). Stimulating student intrinsic motivation to study, could be an effective way to do so $(3,4)$.

Medical students typically have different educational backgrounds and are the product of diverse systems, and have different aspirations, standards, learning methods, adaptive skills and mechanisms to cope with stress and rigors of the program (5). These influences, along with student motivation during their time at medical school, have an important role in their learning and drive to perform on high stake's assessment. In the academic world it is generally accepted that early intervention is important to improve the student success and helps the school and program retain students who are at risk of dropping from courses or programs altogether (6). The importance of early intervention by different forms of assessment has been obvious for a longtime, but has been under appreciated as a beneficial strategy. It has been stated by scholars "the quickest way to change student learning is to change the assessment system" (7). It is also known that the assessment is the single most powerful influence on learning. This holds true for any professional courses, including the medical field.

In academics the assessment can be broadly classified into four types: formative, summative, diagnostic, and benchmark/interim assessment (8). The basic sciences courses use formative and summative assessments to monitor the student's growth towards goals. They evaluate the quality of their work by using formative assessment and compare the student performance against a set of uniform standards by using summative assessment. Formative learning assessment is used to give feedback on their performance and to plan and identify strategies to improve. Typically, the formative learning assessment is carried out concurrently with instructions. Its main purpose is to modify teaching and learning to improve student's learning outcome. Formative assessment is conducted throughout the course or learning module. It is not used for decision making on students' academic progress. On the other hand, summative assessment is used to evaluate the effectiveness of educational environment and to sum up learning. Following a formative learning assessment method, a formative feedback is provided to a learner in a non-threatening and friendly environment which can be used by the student to make changes or modify the learning methods or resources throughout the learning process (9). The educators who have high standards of expectation of their learner group, intentionally invest a large amount of time and efforts in providing a formative feedback to their learner group which is effectively used by students in first or second quartile to optimize their learning (10). In general, if taken together, formative learning tools can be utilized by the faculty and learner to facilitate informed student action to improve student outcome.

Summative learning assessment is used to make decisions about the academic performance and progress of student in the professional program including pass/fail decisions or eligibility for licensure examinations. It determines whether the goals of education are being fulfilled. It is typically formal in nature and conducted at the end of the course or learning module or annually at the same time each school year.

Various researchers like Spolsky et al. (11) have suggested how the formative assessment can be used to provide essential feedback for teachers to assess the subsequent learning activities and experiences in their classroom (5). These activities can also aid to identify and remediate the deficiencies and difficulties in student learning and the knowledge gap. Cauley et al. (12) believed frequent formative assessment involving important concepts and information allows the students to have a better understanding and retention of learning material.

The primary focus of this study was about the effectiveness of formative assessment by the professors in classrooms on the summative high stake's assessment of students in basic science course at an osteopathic medical school (13). The various tools used in formative assessment are low stakes quizzes, team based learning or integrated casebased learning, clinical vignettes during the lecture with quick time or real time audience response system or student self-assessments by take home quizzes $(14,15)$.

\section{MATERIAL AND METHODS}

This study was performed at a University which campuses osteopathic medical school, optometry college, nursing, and undergraduate college in Commonwealth of Kentucky. The university has adopted a discipline based, contextualized and competency driven curriculum which is delivered to osteopathic medical students over a period of 4 years. The medical knowledge to students in basic sciences subjects and clinical sciences subjects are mostly delivered by didactic lecture, but they are interspersed with active learning sessions like case discussions, modified TBL or flipped classroom. The biochemistry and genetics course is delivered in the first semester of the medical school. Every year between July and December, around 145 first year students complete their first semester at the university while gaining medical knowledge in various courses like biochemistry and genetics, gross anatomy and embryology, cell biology, osteopathic patient care, current issues in medicine and osteopathic manipulative medicine. The curriculum is structured as a traditional discipline based by using didactic lectures which are delivered over four blocks for dissemination of medical knowledge in all the courses. Some subjects also utilize active learning methods such as flipped classroom, team-based learning, and case discussions. Various forms of formative and summative assessments are practiced throughout the duration of each block, the types of formative assessment used for assessing medical knowledge are, quizzes using multiple choice questions, clinical vignettes using audience response system, case discussions, take-home quizzes (MCQ), and written assignments. Every student in the cohort had to go through same mechanism of 
assessment. For this study, there was a very important formative quiz a week before the high stake's summative examination. The rationale behind having a formative quiz a week before the summative block exam was to determine students understanding of concepts and assess student's medical knowledge for the content delivered over the block and their readiness for the high stakes block examination $(5,16,17)$ and for faculty or course director to intervene and work with students who may be at risk of gaining unsatisfactory grades. This was intended to help identify and triage students at risk and council them about modifications and methods to improve student understanding and learning of the content delivered to improve performance on high stakes summative assessment.

Each block is delivered over a period of 4-5 weeks and there is a summative examination at the end of each block which tests all the concepts learned in various subjects. The grades achieved by students in each block is utilized to assess student's level of medical knowledge for the block and the entire course overall. Each summative examination is a high stakes assessment delivered using multiple choice questions and is an important milestone in students' progress through each semester and medical school.

This study tried to explore a relationship between student performance in various low stakes quizzes and high stakes examination. The students were grouped into four groups based on their performance in various formative and summative assessment and the final grade average in the fall semester. The students were classified into top quartile who had an average between $91-100 \%$, while $81-90 \%$ as 2nd quartile, $76-80 \%$ as 3rd quartile, and $70-75 \%$ as the bottom quartile.

The study was approved by the Institutional Review Board of University of Pikeville (06.03.2019, 19/0005).

\section{Statistical Analysis}

The statistical software SPSS v.27 was used to analyze the data from the study. The data is represented as mean percentage for the learner group, which was divided into four quartiles including the mean percentage for the assessment method and individual quartile group. The grade point average between the formative assessment and summative assessment were analyzed by using Pearson correlation.

\section{RESULTS}

This study was performed to test whether using a formative mode of assessment methods during the course of content and knowledge delivery would help faculty to identify the learners who may be at risk based on their study methods, understanding of concepts and medical knowledge or any such factors which may have an impact on their performance in high stakes examination. This study included all the 145 students enrolled in 1st year, which comprised of $51.7 \%(n=75)$ female and $48.3 \%(n=70)$ male students, who had finished the fall semester and were part of the cohort of the students who were included in this study and their data and grades analyzed. They all also had an average learning experience of minimum of 5 months and some had around 10-14 months. The general characteristics of the study group were matched by age and learning experience.
All the students have had similar academic experience during the semester with various formative and summative assessment methods. Every student has had four blocks over the course of the semester and there was at least one formative assessment which was mandatory for them to have attempted. The learner group was divided into four group and their grades in formative assessments and summative assessments were correlated to gain statistical information regarding the effect of intervention by the course faculty. As it is evident in the table below, students were first identified as at risk based on their cumulative performance on various formative assessment which was provided to learner group through the course of entire block using quizzes, ARS, clinical vignettes, before the summative examination. Based on analysis, the students grouped in the bottom quartile had strong correlation between their formative assessment results and summative assessment grades. The students in the bottom quartile gained an average of $48.3 \%$ on the formative assessment and $65.7 \%$ on the summative assessment. Similarly, students in top, second and third quartile gained an average of $72.4 \%, 61.0 \%$ and $56.6 \%$ in the formative assessment and gained an average of $89.3 \%, 79.8 \%$ and $75.0 \%$ on their summative high stake's examination. Following this, the students were identified who may be at risk and were advised about modification to study methods and resources being used or new strategy for conceptual understanding and knowledge retention. Following intervention and student advisement there was sustained and gradual improvement in students' performance over the following next formative assessments and high stakes summative assessments in biochemistry and genetics course.

The average student grades in formative assessments for students in bottom quartile were $67.1 \%, 71.7 \%$ and $78.0 \%$ and the respective grades in high stakes summative assessments were $74.9 \%, 77.9 \%$ and $79.9 \%$. This proves that identifying students who may be at risk to gain unsatisfactory results may be assisted by early intervention. Comparatively the students in third quartile scored $74.7 \%, 80.0 \%$ and $82.9 \%$ on formative assessments and $80.7 \%, 82.5 \%$ and $85.0 \%$ on their summative assessment (Table 1).

The relative correlation coefficient for each subsection were also determined using Pearson correlation coefficient, between each formative block quizzes and summative high stakes examination were between moderate to strong correlation. The various $r$ and $p$ values were; $r=0.354 ; p=0.073$ for block $\mathrm{I}, \mathrm{r}=0.549 ; \mathrm{p}=0.048$ for block II, $\mathrm{r}=0.742 ; \mathrm{p}=0.038$ for block III, and $\mathrm{r}=0.510$; $\mathrm{p}=0.023$ for block IV. The students in top and second quartile had similar improvements in their performance after early intervention by faculty or self, which was followed by modifications and better understanding of medical concepts and improved retention of knowledge.

\section{DISCUSSION}

Any university which has an excellent and successful medical curriculum should depend on a satisfactory and encouraging learning environment which includes teaching methodology and feedback system and a valid and acceptable assessment method. The various methods of formative assessment in a curriculum can be used as an 
Table 1. Mean percentages for student groups

\begin{tabular}{lcccccc}
\hline & Top Quartile & Second Quartile & Third Quartile & Bottom Quartile & Course Mean & r and p values \\
\hline Block 1 Formative & 72.4 & 61.0 & 56.6 & 48.3 & 60.2 & $\mathrm{r}=0.354$ \\
Block 1 Summative & 89.3 & 79.8 & 75.0 & 65.7 & 77.4 & $\mathrm{p}=0.073$ \\
Block 2 Formative & 82.9 & 78.0 & 74.7 & 67.1 & 75.7 & $\mathrm{r}=0.549$ \\
Block 2 Summative & 90.9 & 87.7 & 80.7 & 74.9 & 83.5 & $\mathrm{p}=0.048$ \\
Block 3 Formative & 90.0 & 84.3 & 80.0 & 71.7 & 81.4 & $\mathrm{r}=0.742$ \\
Block 3 Summative & 91.1 & 86.6 & 82.5 & 77.9 & 84.5 & $\mathrm{p}=0.038$ \\
Block 4 Formative & 88.2 & 85.4 & 82.9 & 78.0 & 83.6 & $\mathrm{r}=0.510$ \\
Block 4 Summative & 94.0 & 88.3 & 85.0 & 79.9 & 86.8 & $\mathrm{p}=0.023$ \\
\hline
\end{tabular}

This table represents the mean percentages for the different block examinations, average percentages in each quartile group and the correlation between formative assessments and summative assessment percentages for each block for all the students enrolled in the course

effective tool to improve the student's learning outcome and satisfaction. It can also be used as an effective tool to identify at risk students and promote interventions and to aid students to improve their performance on various high stakes examinations.

According to many educators, providing specific feedback and early intervention is the single most important step an educator can do to help students or learner group. When we explain the importance of formative assessments in learning, feedback loop is often explained with it. It can also help most of the students to introspect about their study habits and methods and encourage them to modify them if they feel the result to be unsatisfactory. Based on the above discussion it was evident that students, following their formative assessment, can go back to the drawing board and start modifying the methods to learn the content, ways to improve retention of medical knowledge or identify innovative modes of learning. Over time the students learn to self-assess and both seek and use feedback to focus on improving all areas of their work.

Based on the data analysis for this study, as well it can be construed, this study too like many other studies, prove the importance of early intervention by using formative assessment tools (18-20). As explained before, the results for students who were at risk were offered feedback and enhanced assistance by various departments in terms of both tutoring, immediate feedback and resources which translated with gradual improvement in the student's academic performance. The results in this study were similar to those observed by Mitra et al. (18), which showed positive and significant improvement in summative scores on high stake examination following early and frequent formative testing. This was proved statistically by significant and positive correlation between the grades in formative and summative assessment.

It should be remembered that apart from measurable improvement in student performance, the formative assessment can also provide significant information about the existing learning gap which may not be measured by low or high stakes examination but may be essential for sustained improvement of student's knowledge. It is very important to close the gap between what students currently know and what they are expected to know by the end of the course or curriculum. This observation is similar to that published by Rushton (19), where they used formative assessment for providing constructive feedback and help student in deep learning of the concept and knowledge required. Thus, as noted by various authors, the use of formative assessment in assessing the student's learning or knowledge gap could be extremely impactful in making early intervention and providing feedback and modifying the learning environment to improve student performance $(12,21,22)$.

\section{CONCLUSION}

Our data suggests that using formative assessment tools frequently, and providing directed feedback using results of the formative assessment as an early intervention strategy resulted in significant student performance improvements on summative examinations. In general, based on informal feedback, the students prefer increased use of formative assessment in terms of take home quizzes, pop quizzes, case discussions during lectures or team based/problem based sessions, assuming that the discussion with the learner group was relatively immediate. However, although almost all students were in favor of using this method for bridging the learning gap, a subset of students expressed reservations about the spontaneity of timing for such activities as it may distract from focus on other courses, or set the stage for self-doubt as the formative assessment is not a reflection of their knowledge gained for subsequent study. Though it should be stressed that formative assessments remain an important tool for the students to minimize their knowledge gap and encourages the development of critical thinking skills.

Ethics Committee Approval: The study was approved by the Institutional Review Board of University of Pikeville (06.03.2019, 19/0005).

Conflict of Interest: None declared by the authors.

Financial Disclosure: None declared by the authors.

Acknowledgements: None declared by the authors.

Author Contributions: Idea/Concept: VJ; Design: MY; Data Collection/Processing: VJ; Analysis/Interpretation: SK; Literature Review: BJ; Drafting/Writing: VJ; Critical Review: MY, BJ. 


\section{REFERENCES}

1. Larsen DP, Butler AC, Roediger HL 3rd. Testenhanced learning in medical education. Med Educ. 2008;42(10):959-66.

2. Walker DJ, Topping K, Rodrigues S. Student reflection on formative e-assessment: expectations and perceptions. Learn Media Technol. 2008;33(3):221-34.

3. Agarwal S, Norman GR, Eva KW. Influences on medical students self-regulated learning after test completion. Med Educ. 2012;46(3):326-35.

4. Adams T, Webster B. Retention and confidence: the impact of confidence-based learning on knowledge retention. 2010.

5. Das S, Alsalhanie KM, Nauhria S, Joshi V, Khan S, Surender V. Impact of formative assessment on the outcome of summative assessment - a feedback based cross sectional study conducted among basic science medical students enrolled in MD program. Asian J Med Sci. 2017;8(4):38-43.

6. Prideaux D. Researching the outcomes of educational interventions: a matter of design. RTCs have important limitations in evaluating educational interventions. BMJ. 2002;324(7330):126-7.

7. Epstein RM. Assessment in medical education. N Engl J Med. 2007;356(4):387-96.

8. Aftab MT, Tariq MH. Continuous assessment as a good motivational tool in medical education. Acta Med Acad. 2018;47(1):76-81.

9. Black P, William D. Assessment and classroom learning. Assess Educ Princ Pol Pract. 1998;5(1):7-74.

10. Krasne S, Wimmers PF, Relan A, Drake TA. Differential effects of two types of formative assessment in predicting performance of first-year medical students. Adv Health Sci Educ Theory Pract. 2006;11(2):155-71.

11. Spolsky B, Hult FM. The handbook of educational linguistics. 1st ed. Malden, MA: Blackwell Pub.; 2008.
12. Cauley KM, McMillan JH. Formative assessment techniques to support student motivation and achievement. The Clearing House: A Journal of Educational Strategies, Issues and Ideas. 2010;83(1):16.

13. Gaytan J. Effective assessment techniques for online instruction. Inf Technol Learn Perform J. 2005;23(1):25-34.

14. Crooks TJ. The impact of classroom evaluation practices on students. Rev Educ Res. 1988;58(4):43881.

15. Butler DL, Winne PH. Feedback and self-regulated learning: a theoretical synthesis. Rev Educ Res. 1995;65(3):245-81.

16. Henley DC. Use of Web-based formative assessment to support student learning in a metabolism/nutrition unit. Eur J Dent Educ. 2003;7(3):116-22.

17. Sadler DR. Formative assessment and the design of instructional systems. Instr Sci. 1989;18(2):119-44.

18. Mitra NK, Barua A. Effect of online formative assessment on summative performance in integrated musculoskeletal system module. BMC Med Educ. 2015;15:29

19. Rushton A. Formative assessment: a key to deep learning? Med Teach. 2005;27(6):509-13.

20. Nicol DJ, Macfarlane-Dick D. Formative assessment and self-regulated learning: a model and seven principles of good feedback practice. Stud High Educ. 2006;31(2):199-218.

21. Vaz M, Avadhany ST, Rao BS. Student perspectives on the role of formative assessment in physiology. Med Teach. 1996;18(4):324-26.

22. Chisnall B, Vince T, Hall S, Tribe R. Evaluation of outcomes of a formative objective structured clinical examination for second-year UK medical students. Int J Med Educ. 2015;6:76-83. 